\title{
Testing the Wagner's Hypothesis on Public Expenditure and Output Growth Causality in Nigeria
}

\author{
Ekiran Joseph O. (Ph.D) Ogungbenle Sola (Ph.D) \\ Department of Economics, College of Education, Ikere Ekiti, Ekiti State, Nigeria
}

\begin{abstract}
This study tests the validity of Wagner's hypothesis on public expenditure and output growth in Nigeria from 1970 - 2016 using annual time series data. Phillips Perron unit root test (PP), Johansen cointegration test, Vector Error Correction Model (VECM) and pair wise Granger causality econometric analytical methods were employed. The stationary property of the research variables was confirmed and other tests in the study revealed a unidirectional causation from government expenditure to economic growth in the country. The finding of the study therefore invalidates the applicability of Wagner's hypothesis in Nigeria within the study period. The study recommends the need for appropriate policies on effective utilization of public fund knowing that it has positive effect on the level of economic growth in the country.
\end{abstract}

Keywords: Wagner's hypothesis, Output Growth, Public Expenditure, Cointegration, VECM, Causality.

DOI: $10.7176 /$ RHSS/9-24-09

Publication date: December $31^{\text {st }} 2019$

\section{Introduction}

Output growth and public expenditure have been a subject of extensive theoretical and empirical investigation over time. Wagner's law is one of the first and most widely used model for the determination of public expenditure in relation to national output. The law identified that public expenditure is an endogenous variable to the growth of national income. It suggests that causality runs from national income to public expenditure, indicating a long run tendency for public expenditure to increase as the real income per capita of a nation increases (Wagner, 1883, 1912). In contrast with Keynes's hypothesis which state that public expenditure is an exogenous factor and a policy instrument for increasing national income, Wagner's model viewed that public expenditure is an effect rather than a cause of national income, hence it plays no role in generating national income.

It has been established in literature that empirical analysis of the Wagner's law has produced mixed results. While some studies (Wagner and Weber, 1977; Abisadeh and Gray, 1985; Chang, 2002; Aregbeyen, 2006; Matthew and Oguntegbe, 2013 and Aniefiok and Charles (2014) have found support for the Wager's Law, some other studies (Afxentiou and Serletis, 1996; Burney, 2002; Huang, 2006; Owolabi, 2015and Anoke, 2016) have found non-existence support for the law. The main reasons for the diversity in the previous studies may be traced to the differences in the data coverage and the research method adopted. Based on the dynamic nature of the volume of government income and expenditure in Nigeria, this study believes that a more recent study of this type will produce a more reliable result that will serve as an effective policy instrument for stake holders in the country.

In addition, in establishing the causal relationship between public spending and output growth in Nigeria, the use of Granger causality test has been identified by several studies (Toda and Philips, 1993; Dolado and Lutkepohl, 1996; Tsen, 2006; Aniefiok and Charles, 2014 and Yaya, 2016). Most of these authors like Dolado and Lutkepohl (1996) and Aniefiok and Charles (2014) ignored the issue of spurious regression in modeling. According to Gujarati and Dawn (2009), in the presence of autocorrelation, ordinary least square estimators are not efficient, leading to misleading conclusions of the estimated regression coefficients. It is the aim of this study to bridge the identified gaps in the literature and to test the Wagner's hypothesis on public expenditure and output growth causality in Nigeria.

\section{Literature Review}

\subsection{Theoretical Literature}

The German economist, Adolph Wagner (1883) developed a law of increasing state activity. He declared that there is a long run tendency for the spending capacity of government to rise with higher levels of economic progress. He predicted the expansion of 'cultural and welfare' spending based on the presumption that as income rises, society would demand for more education, entertainment, income and public services (Anoke, 2016).

Since the original formulation of the Wagner's proposition, six different version of the Wagner model have been specified, using different variables to approximate the theoretical government expenditure and economic growth variables. As indicated in Otu and Nsikan (2015), the functional forms of the Wagner models are as follow: $\log (\text { RTGE })_{t}=\alpha_{1}+\beta_{1} \log \left(\right.$ RGDP $\left._{t}\right)+\mu_{1 t}($ Peacock and Wiseman, 1961) $\ldots . . .1$

$\log \left(\right.$ RTGE $_{t}=\propto_{2}+\beta_{2} \log \left(\right.$ RGDP $_{t} /$ POP $\left._{t}\right)+\mu_{2 t}($ Goff man, 1968) $\ldots \ldots \ldots \ldots \ldots . . . .2$

$\log \left(\frac{\mathrm{RTGE}_{t}}{\mathrm{POP}_{t}}\right) \quad=\alpha_{3}+\beta_{3} \log \left(\mathrm{RGDP}_{\mathrm{t}} / \mathrm{POP}_{\mathrm{t}}\right)+\mu_{3 \mathrm{t}}($ Gupta, 1976) $\ldots \ldots \ldots \ldots \ldots \ldots . . . . . . . .3$ 


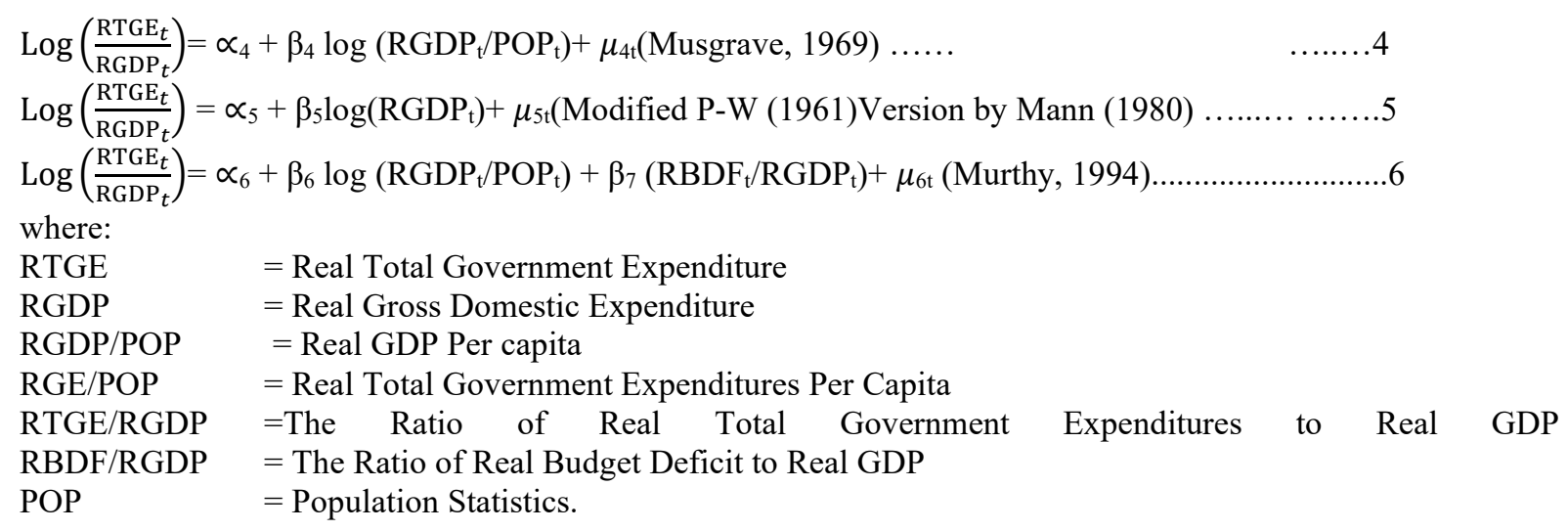

\subsection{Conceptual and Empirical Literature}

The pattern of government expenditure in Nigeria has been on consistent increase over the years. According to Tsenba and Gushibet (2016), achieving sustained economic growth is a principal objective of government expenditure policy and the relationship between the government expenditure and economic growth is an important subject of analysis and debate.

Government expenditure refers to the spending made by the government of a country on specific and collective needs. Government expenditures are usually categorized into recurrent and capital expenditures. While the former refer to financial outlays necessary for day-to-day running of government activities, the latter refers to investment projects that increases national assets (Agbonkhese and Asekome, 2014).

Economic growth is the percentage increase in the growth rate of gross domestic product per annum, resulting from factors of production. Ideally, the growth is brought about by improvement in availability of health infrastructure, housing, education and good roads e.t.c. It brings about a better standard of living of the people.

There have been a plethora of empirical studies that have attempted to investigate the validity of Wagner's Law in both developed and less developed economies. In an investigation to examine whether there was empirical evidence in support of Wagner's law in Sri Lankan economy between 1960 and 2010, Kesavarajah (2012) using co-integration and error correction modeling, confirmed non-existing long-run relationship between public expenditure and economic growth.

Matthew and Oguntegbe (2013) examined the causality between economic growth and government spending in Nigeria during 1961 to 2011. The study indicated an existence of Wagner's law in Nigeria within the study period.

One the contrary, Owolabi (2015) investigated the Wagnerian view on public expenditure and economic growth in Nigeria using annual secondary data spanning from 1980 to 2011. The finding of the study indicated a non-existence of Wagner's law in Nigeria during the period under review.

Tsenba and Gushibet (2016) used Granger causality model to examine the nexus between government expenditure and economic growth in Nigeria from 2000 to 2014. The study revealed a unidirectional causation from government expenditure to economic growth in the country.

\section{Methodology}

\subsection{Sources of Data}

This empirical study relied on secondary data sourced from the Central Bank of Nigeria (CBN) statistical Bullentin (Various Issues) and from the Review of the Nigerian Economy published by the National Bureau of Statistics (NBS). The study covers the period between 1980 and 2016.

\subsection{Model Specification}

In a broad term, there are diverse models of Wagner's theory. This study adopted the Peacock and Wiseman version of the theory because it is the first and the only model that specified the original hypothesis of Adolph Wagner (our focus of study) as described in equation 1 to 6 above. The Peacock and Wiseman's model states that: $\mathrm{RTGE}_{\mathrm{t}}=\mathrm{f}\left(\mathrm{RGDP}_{\mathrm{t}}\right)$ .7

Adding some relevant control variables, we have:

$\mathrm{RTGE}_{\mathrm{t}}=\mathrm{f}\left(\mathrm{RGDP}_{\mathrm{t}}, \mathrm{RTIM}_{\mathrm{t}}, \mathrm{RTEX}_{\mathrm{t}}\right.$ .8

The model, in regression form becomes:

$\mathrm{RTGE}_{\mathrm{t}}=\propto_{0}+\propto_{1} \mathrm{RGDP}_{\mathrm{t}}+\propto_{2} \mathrm{RTIM}_{\mathrm{t}}+\propto_{3} \mathrm{RTEX}_{\mathrm{t}}+e_{\mathrm{t}} \ldots \ldots \ldots \ldots \ldots \ldots \ldots \ldots . . \ldots$

Putting the model in the natural logarithms in order to convert research data to the same numerical structure, we have:

LRTGE $_{\mathrm{t}}=\propto_{0}+\propto_{1} \mathrm{LRGDP}_{\mathrm{t}}+\propto_{2} \mathrm{LRTIM}_{\mathrm{t}}+\propto_{3} \mathrm{LRTEX}_{\mathrm{t}}+e_{t}$ 


\section{where:}

LRTGE $=$ Log of Real Total Government Expenditure

LRGDP $=$ Log of Real Gross Domestic Product at current market price (A proxy for output/economic growth)

LRTIM $=$ Log of Real Total Import

LRTEX $=$ Log of Real Total Export

$\propto_{0}, \propto_{1}-\propto_{3}, e_{\mathrm{t}}=$ Intercept, estimated coefficients and error term respectively

\subsection{Estimation Techniques}

The methods of estimation employed for this study are based on Johansen cointegration test, Vector Error Corrections Model (VECM) and pairwise Granger causality test for long run and short run analyses respectively. The study analysed time series properties of the research variables using Phillips Perron (PP) unit root test.

The PP stationarity test is found in use in the literature by most of the studies like Sikiru and Umaru (2009) Chigbu, Akujuobi and Appah (2011) and Yaya (2016) because the test employs non parametric statistical methods to take care of the serial correlation in the error terms (Gujarati and Dawn, 2009).

Johansen cointegration test is conducted to examine Lon-rung relationship between the series of the same order of integration. Lack of cointegration implies no long-run relationship between research variables.

Vector Error Correction Model (VECM) reconciles the short run behavior of multi-variate research models with long run dynamics. The VECM of the above equation 10 is:

$$
\begin{aligned}
& \Delta L R T G E_{t}=\propto_{0}+\propto_{1} \text { ECT }_{t-1}+\sum_{j=1}^{k} \propto_{2 j} \Delta L R T G E_{t-1}+\sum_{j=1}^{k} \propto_{3 j} \Delta L R G D P_{t-j}+\sum_{j=1}^{k} \propto_{4 j} \Delta L R T I M_{t-j}
\end{aligned}
$$

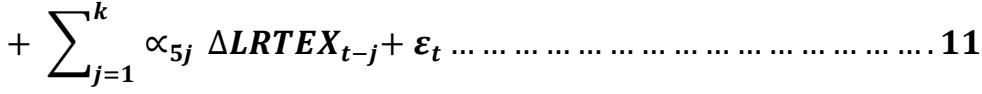

where: $\mathrm{ECT}_{\mathrm{t}-1}$ is the error correction term, $\varepsilon_{\mathrm{t}}$ is the random disturbance term and $\mathrm{k}$ is the number of the lags necessary to obtain white noise.

Granger causality regresses each variable on lagged values itself and the others to determine whether the current and lagged values of one variable affect another (Godwin and William, 2010). The test answers the questions of whether $\mathrm{X}$ causes $\mathrm{Y}$ or $\mathrm{Y}$ causes $\mathrm{X}$. $\mathrm{Y}$ is said to be granger caused by $\mathrm{X}$ if $\mathrm{X}$ helps in the prediction of $Y$, or if the coefficients of the lagged $X$ 's are statistically significant.

\section{Results and Discussion of Findings}

\subsection{Unit Root Test}

The purpose of the test is to verify the stationary of all the variables specified for estimation in this study. Table 1: Result of Phillips - Perron Unit Root Test

\begin{tabular}{|l|l|l|l|l|l|l|l|}
\hline \multirow{2}{*}{ VARIABLE } & AT LEVELS & \multicolumn{1}{|l|}{ 1st DIFFERENCE } & \multirow{2}{*}{ Level of Integration } \\
\cline { 2 - 8 } & $\begin{array}{l}\text { PP- } \\
\text { Test }\end{array}$ & $\mathbf{1 \%}$ C.V. & $\mathbf{5 \%}$ C.V. & PP-Test & $\mathbf{1 \%}$ C.V. & $\mathbf{5 \%}$ C.V. & \multirow{2}{*}{} \\
\hline LRTGE & -2.4986 & -3.6009 & -2.9350 & $-8.4689 * *$ & -3.6056 & -2.9369 & $\mathrm{I}(1)$ \\
\hline LRGDP & -1.5478 & -3.6009 & -2.9350 & $-6.7888 * *$ & -3.6056 & -2.9369 & $\mathrm{I}(1)$ \\
\hline LRTIM & 1.4187 & -3.6009 & -2.9350 & $-8.5644 * *$ & -3.6056 & -2.9369 & $\mathrm{I}(1)$ \\
\hline LRTEX & -0.0742 & -3.6009 & -2.9350 & $-7.6653 * *$ & -3.6056 & -2.9369 & $\mathrm{I}(1)$ \\
\hline
\end{tabular}

NOTE: $* *$ indicates significance at both $1 \%$ and $5 \%$ levels

Source: Authors' Computation (2018), using E-View

The above result as shown in Table 1 indicates that all the research variables are non-stationary at levels $[\mathrm{I}(\mathrm{O})]$ but are stationary in the first different [I(1)].At this point, all PP - test statistics in the table are less than the critical values, even at $1 \%$ significance level. The situation leads to the rejection of the null hypothesis and confirmed that the series are all integrated of order one, I(1).

\subsection{Johansen Cointegration Test}

The existence of the long-run properties in the above stationarity test actually justified the application of Johansen cointegration analysis as shown below: 
Table 2: Cointegration Test Results

\begin{tabular}{|l|l|l|l|l|l|}
\hline $\begin{array}{l}\text { Hypothesized Number of } \\
\text { Cointegration Equations }\end{array}$ & $\begin{array}{l}\text { Eigen } \\
\text { Value }\end{array}$ & $\begin{array}{l}\text { Trace } \\
\text { Statistic }\end{array}$ & $\begin{array}{l}\text { Critical Value } \\
\text { at 5\% } \\
\text { (p-value) }\end{array}$ & $\begin{array}{l}\text { Maximum } \\
\text { Eigen Statistic }\end{array}$ & $\begin{array}{l}\text { Critical Value at } \\
5 \% \text { (p-value) }\end{array}$ \\
\hline None* & 0.765629 & 90.42 & $47.86(0.00)$ & 58.03 & $27.58(0.00)$ \\
\hline At most 1* & 0.412828 & 32.38 & $29.80(0.02)$ & 21.30 & $21.13(0.05)$ \\
\hline At most 2 & 0.202422 & 11.08 & $15.49(0.21)$ & 9.05 & $14.27(0.28)$ \\
\hline At most 3 & 0.049627 & 2.04 & $3.84(0.15)$ & 2.04 & $3.84(0.15)$ \\
\hline
\end{tabular}

Note: * denotes rejection of the hypothesis of no conintegration at $5 \%$ level.

Source: Authors' Computation (2018), using E-view.

The result of the Johansen cointegration test as shown in Table 2 above confirmed that both the Trace and Maximum Eigen tests reject the hypothesis of no cointegration at 5\% level of significance. This implies that there is the presence of a long run Cointegration relationship between public expenditure and economic growth in Nigeria.

The result warrants the use of Vector Error Correction Mechanism (VECM) to model the long-run causal relations between the concerned variables.

\subsection{Result of Vector Error Correction Model (VECM) Test.}

The VECM estimates are shown in Table 3 below:

Table 3: Result of VECM Test

\begin{tabular}{|c|c|c|}
\hline Variables & $\Delta L R T G E_{t}$ & $\Delta L R G D P_{t}$ \\
\hline $\begin{array}{l}\mathrm{ECMt}_{-1} \\
\text { (Standard Error) } \\
(\mathrm{t}-\text { Statistic) }\end{array}$ & $\begin{array}{l}0.000277 \\
(7.2 \mathrm{E}-05) \\
\{3.83227\} \\
\end{array}$ & $\begin{array}{l}0.000288 \\
(0.00035) \\
\{0.81030\} \\
\end{array}$ \\
\hline $\begin{array}{l}\Delta \boldsymbol{L} \boldsymbol{R T} \boldsymbol{G} \boldsymbol{E}_{t-\mathbf{1}} \\
\text { (Standard Error) } \\
(\mathrm{t}-\text { Statistic) }\end{array}$ & $\begin{array}{l}-8.674640 \\
(4.59505) \\
\{-1.88782\}\end{array}$ & $\begin{array}{l}-9.670083 \\
(22.5900) \\
\{-0.42807\}\end{array}$ \\
\hline $\begin{array}{l}\Delta \boldsymbol{L R} \boldsymbol{R} \boldsymbol{D P} \boldsymbol{P}_{t-\mathbf{1}} \\
\text { (Standard Error) } \\
(\mathrm{t}-\text { Statistic) }\end{array}$ & $\begin{array}{l}0.090323 \\
(0.04846) \\
\{1.86378) \\
\end{array}$ & $\begin{array}{l}0.167402 \\
(0.23825) \\
\{0.70264\} \\
\end{array}$ \\
\hline $\begin{array}{l}\Delta \boldsymbol{L} \boldsymbol{R T I M} \boldsymbol{M}_{\boldsymbol{t}-\mathbf{1}} \\
\text { (Standard Error) } \\
(\mathrm{t}-\text { Statistic) }\end{array}$ & $\begin{array}{l}0.682066 \\
(0.23939) \\
\{2.84914\} \\
\end{array}$ & $\begin{array}{l}0.818898 \\
(1.17690) \\
\{0.69581\} \\
\end{array}$ \\
\hline 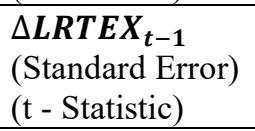 & $\begin{array}{l}-0.485566 \\
(0.15729) \\
\{-3.08703\}\end{array}$ & $\begin{array}{l}-0.667257 \\
(0.77327) \\
\{-0.86290\}\end{array}$ \\
\hline $\begin{array}{l}\text { C } \\
\text { (Standard Error) } \\
(\mathrm{t} \text { - Statistic) }\end{array}$ & $\begin{array}{l}1257.602 \\
(564.325) \\
\{2.22851\}\end{array}$ & $\begin{array}{l}146.3495 \\
(2774.32) \\
\{0.05275\}\end{array}$ \\
\hline
\end{tabular}

Source: Authors' computation (2018), using E-view

The above VECM result confirmed that the $\mathrm{ECM}_{\mathrm{t}-1}$ coefficient for the total government expenditure $(\triangle \boldsymbol{L R T G E})$ is statistically significant at $5 \%$ level since the $\mathrm{t}_{\text {cal }}=3.83227>\mathrm{t}_{\mathrm{n}-\mathrm{k}}=\mathrm{t}_{40-4}=2.03$ while the $\mathrm{ECT}_{\mathrm{t}-1}$ coefficient for $\Delta \boldsymbol{L} \boldsymbol{R} \boldsymbol{G D P}$ equation is not significant since $\mathrm{t}_{\text {cal. }}=0.81030<\mathrm{t}_{40-4}=2.03$ at $5 \%$ level. This indicates that longrun unidirectional causality runs from total government expenditure to economic growth in Nigeria.

This study went further to find out the shortrun causal relationship of the research variables, using pairwise Granger causality test as presented below:

\subsection{Granger Causality Test}

Table 4: Pairwise Granger Causality Test Estimate

\begin{tabular}{|l|l|l|l|l|}
\hline Null Hypothesis & Observation & F-statistic & Probability & Decision \\
\hline RTGE does not Granger cause RGDP & 40 & 3.5001 & $0.0411^{* *}$ & Reject null hypothesis \\
\hline RGDP does not Granger cause RTGE & 40 & 1.2429 & 0.3010 & Accept null hypothesis \\
\hline RTGE does not Granger cause RTIM & 40 & 0.6591 & 0.5236 & Accept null hypothesis \\
\hline RTIM does not Granger cause RTGE & 40 & 1.9549 & 0.1567 & Accept null hypothesis \\
\hline RTGE does not Granger cause RTEX & 40 & 0.6587 & 0.5238 & Accept null hypothesis \\
\hline RTEX does not Granger cause RTGE & 40 & 4.2215 & $0.0228^{* *}$ & Reject null hypothesis \\
\hline
\end{tabular}

Note: $* *$ indicates rejection of the null hypothesis at $5 \%$ level of significance

Source: Authors' Computation (2018), using E-View 
The result of the Granger causality test is as presented in Table 4 above. Evidence exists from the result that total government expenditure Granger caused economic growth in the short run during the period of the study. The position was confirmed with the f-statistic figure of 3.5001 and the probability value of 0.0411 which suggested the rejection of the null hypothesis at 5\% level of significance for the RTGE (Real total government expenditure) variable.

\section{Conclusion and Policy Recommendations}

This paper has examined the long run as well as the short run relationship between public expenditure and economic growth to test the applicability of the Wagner's hypothesis in Nigeria.

The study concluded that both the longrun and shortrun causality run from total government expenditure (RTGE) to output growth (RGDP) in the country. This indicates that Wagner's Law is not supported and that the law is not a reality but an ordinary myth in Nigeria during the period under investigation. The result of the study conforms with those of Kesavarajah (2012) and Owolabi (2015) but conflicts with the findings of Aniefiok and Charles (2014) and Tsenba and Gushibet (2016). The study recommends that government should put appropriate fiscal policy in place in order to increase government expenditure for attaining economic growth objective in Nigeria.

\section{References}

Abisadeh, S., \& Gray, J. (1985).Wagner's Law: A pooled Time-Series Cross-Section Comparison, National Tax Journal, 88, 209-218.

Afxentiou, P.C., \& Serletis, A. (1996). Government Expenditures in the European Union: Do They Coverage or Follow Wagner's Law? International Economic Journal 10, 33-47.

Agbonkhese, A.O., \& Asekome, M.O. (2014). Impact of Public Expenditure on the Growth of Nigerian Economy, European Scientific Journal, 28, 219 - 229.

Aniefiok, U., \& Charles, E. (2014). Economic Growth and Wagner's Hypothesis: The Nigerian Experience, Journal of Economic and Sustainable Development, 5(16), 41-58.

Anoke, C.I. (2016). Testing the Applicability of Wagner's Law in Nigeria, Journal of Research in Business and Management, 4 (6), 33-45

Aregbeyen, O. (2006). Co-Integration Causality and Wagner's law: A Test for Nigeria, 1970-2003. Central Bank of Nigeria Economic and Financial Review, 44, 2.

Burney, N.A. (2002). Wagner's Hypothesis: Evidence from Kuwait, Using Co-Integration Test, Applied Economics, 34, 49-57.

Chang, T. (2002). An Econometric Test of Wagner's Law for six countries, based on co-integration and Error correction Modelling Techniques, Applied Economics, 34, 1157-1169.

Chigbu, E.E., Akujuobi, L.E., \& Appah, E. (2011). An Empirical Study on the Causality between Economic Growth and Taxation in Nigeria, Current Research Journal of Economic Theory, 4(2), 29-38.

Dolado, J.J., \& Lutkepohl, H. (1996). Making Wald Tests work for Co-integrated VAR Systems, Econometric Review, 15(4), 369 -386.

Godwin, C.O., \& William, C. N. (2010). Government Expenditure, Money Supply, Prices and Output Relationship in Nigeria, International Research Journal of Finance and Economics, 2010(54), 125 - 133.

Goffman, I. J. (1968). On the Empirical Testing of Wagner's law: A technical Note, Public Finance, 23, 359 364.

Gujarati, D. M.,\& Dawn, C.P. (2009). Basic Econometrics, Singapore: Macgraw Hill Companies.

Gupta, S.(1967). Public Expenditure and Economic Growth: A Time Series Analysis, Public Finance, 22(4), 423 $-461$.

Huang, C.J. (2006). Government Expenditures in China and Taiwan: Do They Follow Wagner's Law? Journal of Economic Development, 31(2).

Kesavarajah, M.(2012).Wagner's Law in Sri Lanka: An Econometric Analysis. ISRN Economics, 1, 1-9.

Keynes, J.M. (1936). The General Theory of Employment, Interest and Money. New York: Harcourt Brace Publishers.

Mann, A.J. (1980). Wagner's Law: An Econometric Test for Mexico, 1925-76. National Tax Journal, 33(2), 189201.

Matthew, A.D., \& Oguntegbe, A.A. (2013). Is Wagner's Law a Myth or a Reality?, Empirical Evidence from Nigeria, International Journal of Development and Economic Sustainability, 1(1), 123 - 137.

Murthy, V. (1994). Wagner's Law, Spurious in Mexico or Mis-specification: A Reply, Public Finance, 49(2), 295 303.

Musgrave, R.A. (1969).Fiscal System, New Haven; Yale University Press.

Otu, W. I., \& Nsikan, E. B. (2015). Wagner's Law Revisited: The Case of Nigeria Agricultural Sector, International Journal of Food and Agricultural Economics, 2(3), 19-32. 
Owolabi, M.O. (2015). Re-examining the Wagner's Law versus Keynesian Hypothesis: Evidence from Nigeria, International Letters of Social and Humanistic Sciences, 57, 142-146.

Peacock, A. T., \& Wiseman, J. (1961). The Growth of Public Expenditure in the United Kingdom, London: Oxford university press.

Sikiru, J.B, \& Umaru, A. (2009). Fiscal Policy and Economic Growth Relationship in Nigeria. International Journal of Business and Social Sciences, 2(17), 244 - 249.

Toda, H.Y., \& Phillips, P. (1993). Vector Auto regression and Causality, Econometrica, 61, 1367 - 1393.

Tsen, W. (2006). Granger Causality Tests in China: 1952-1999. International Economics Journal, 20(3), 285 302

Tsenba, W.S.B., \& Gushibet, S. T. (2016). Causality between Government Expenditure and Economic Growth in Nigeria, International Journal of Advanced Studies in Business Strategies, 4(1), 2354-4244.

Wagner, A.H. (1883).Finanzwissenscaft, Paris: Leipzig

Wagner, A.H. (1912).Les fondements de l'economie, Politique. Paris: Girard and Briere.

Wagner, R.E., \& Weber, W.E. (1977).Wagner's Law, Fiscal institution and the growth of Government, National Tax Journal, 30, 59-68.

Yaya, K. (2016). Testing Wagner's Law in the Presence of Structural Changes: New Evidence from six African countries, International Journal of Economics and Financial Issues, 6(1), 1-6. 